\title{
ANGABEN ZUR FRAGE DER TOLERANZ \\ DER GROSSBETRIEBLICHEN HALTUNGSTECHNOLOGIE \\ BEI MILCHKUHBESTÄNDEN VERSCHIEDENEN GENOTYYS
}

I. Cstkly, J. Dohy, J. Rerı, B. Szullo. - Hungarian Research Institute for Animal Husbandry, 20.53 Herceghalom and Lajta-Hansag State Farm, 9200 Mosonmagyarovar, Hungary.

Verfasser untersuchten die Tolerationsfähigkeit von Ungarischen Fleckvieh- und 25 p. I0o Jersey Genateil führenden Kreuzungskühen unter grossbetrieblichen Haltungsbedingungenganzjährige Stallhaltung, Anbindehaltung, Kurzstand, Rohrmelkanlage/in einem Zeitraum von 3 Jahren. Die Ergebnisse sind in Tabellen zusammengefasst. Auf Grund ihrer Untersuchungen und Erfahrungen stellten Verfasser fest, dass die Kuhpopulation mit 25 p. I oo Jersey Genanteil. "Ung. Fleckvieh vom Milchtyp"/ die durch die Haltungstechnologie verursachtendauerhaften Stresswirkungen bedeutend besser toleriert haben, als die gleichaltrigen Ung. Fleckvieh-Stallgeführten.

\section{PRELIMINARY RESULTS FROM STUdIES ON DIFFERENT MEASUREMENTS OF BULL'S FERTILITY}

H. Haxsex. - Department of Cattle Experiments, National Institute of Animal Science 25 Rolighedsvej, 1958 Copenhagen $V$, Denmark.

In the present paper results from a preliminary analysis of bull's fertility are reported.

The data consist of 1.004 .960 first inseminations from 4 Al societies. The sire breeds are Red Danish, Black Pied Danish and Danish Jersey, and the fertility measures examined are non return rates (NR-p. 100), I 8-24 days, 30-60 days and 60-90 days resp.

The NR-p. Ioo for the Red Danish was lower than for the two other breeds as regards 30-60 and 60-90 days NR-p. 100. This might partly be due to a higher frequency of embryonic mortality.

The heritability estimate for the chance of conceiving after insemination with a certain bull was calculated for each breed-NR-p. roo group, the range of the estimates being 0.019-0.036.

\section{BREEDING AND SELECTION FOR BEHAVIOUR IN DAIRY CATTLE}

\section{J. Czako. University of Agricultural Sciences, Gödöllö, Ungary.}

The selection according to behaviour representing the technological tolerance is very important among conditions of industrial type cattle keeping. While the technological surroundings change suddenly and in considerable extent, the behaviour characteristics of species have not or scarcely changed. Based on the researches till now the behaviour characteristics have been known, but thery are not used in selection.

The examinations of three groups of cows have pointed out that the technological tolerancel rutting process, blood temperature during milking, rumination and resting during manua/ works in cow-shed, behaviour against workers/ of individual populations were different when the conditions were identical. The process of rutting proved to be most unfavourable for Hungarian Fleckvieh. On the other hand the manual work doing in cow-shed after feeding disturb the Hungarian Fleckvieh cows in the least extent.

According to examinations the feeding time of five progeny testing groups of Hungarian Flekvieh bulls were different among standard conditions of progeny-testing station. However their production was approximately the same. The contrary of results would be desirable. 